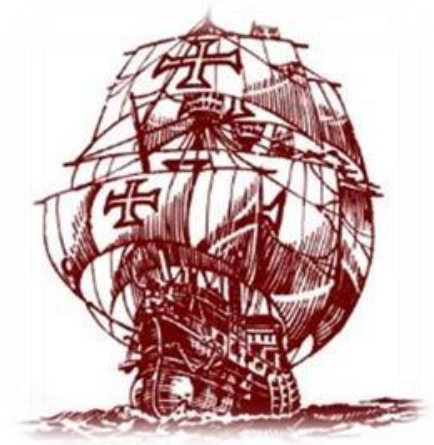

\author{
Nau Literária: crítica e teoria de literaturas \\ www.seer.ufrgs.br/nauliteraria \\ ISSN 1981-4526 - PPG-LET-UFRGS - Porto Alegre \\ Vol. 11 N. 02 \\ Literatura e Guerra
}

\title{
MAYOMBE: UMA VISÃo INTERNA DA GUERRA COLONIAL DE AN- GOLA
}

\section{BIANCA RODRIGUES BRATKOWSKI ${ }^{\mathrm{i}}$}

Resumo: O presente artigo traz uma reflexão sobre Mayombe, evidenciando a época de escrita da obra, as experiências do próprio escritor como guerrilheiro e, ainda, a maneira como as personagens veem o MPLA e participam da Guerra Colonial.

Palavras-chave: Mayombe; Pepetela; Guerra Colonial; MPLA.

\begin{abstract}
Mayombe, highlighting the writing period of the work, the writer 's own experiences as a guerrilla, and the way in which the characters see the MPLA and participate in the Colonial War.
\end{abstract}

Keywords: Mayombe; Pepetela; Colonial War; MPLA.

A guerra é representada constantemente na literatura e contempla diferentes períodos históricos e sociedades, porque "há sempre uma guerra acontecendo em algum lugar do mundo" (OZ, 1999, p. 31), como bem afirmou o narrador de Pantera no porão. Similarmente, Freud assinala que

basta dar uma olhada à história da humanidade para assistirmos a um desfile ininterrupto de conflitos, seja entre uma comunidade em luta com outra ou outras, seja entre unidades por vezes grandes por vezes mais pequenas, entre cidades, países tribos, povos ou impérios, conflitos quase sempre decididos pelo sacrifício das suas forças ao longo de uma guerra (FREUD, 2007, p. 45-46).

O fato de que os povos estão sempre em luta torna essa temática um campo abundante para os escritores, permeando diversas obras literárias desde muito tempo, especialmente quando os autores, de alguma forma, a vivenciaram em alguma etapa de sua existência. Muitos escritores foram combatentes e dedicaram-se a narrar essas experiências, alguns muito tempo depois do ocorrido, outros durante a guerra. Em Literatura e Guerra, Elcio Cornelsen chama a atenção para o fato de que as narrativas de guerra frequentemente escritas por combatentes não apresentam uma visão de guerra sempre uniforme, mas estão intrinsecamente associadas à vivência da própria guerra (CORNELSEN; BURNS, 2010, p. 11).

O escritor angolano Pepetela mostra, em Mayombe, sua visão da Guerra Colonial e do Movimento Popular de Libertação de Angola do qual participou. A Guerra Colonial ocorreu entre 1961 e 1974, quando as Forças Armadas Portuguesas estiveram em confronto com os movimentos de libertação de Angola, Moçambique e Guiné. Em Angola, vários movimentos se formaram visando à independência do país, como o MPLA (Movimento Popular de Libertação de Angola), a UNITA (União Nacional pela Independência Total de Angola) e a FNLA (Frente Nacional de Libertação de Angola). 
Quando movimentos culturais promovidos pelos angolanos começaram a surgir, em 1960, a polícia portuguesa reagiu, prendendo vários integrantes do MPLA, formado por muitos intelectuais e escritores. Em 1961, ocorreu a primeira luta armada do movimento para a libertação desses militantes, e Portugal contra-atacou:

Portugal fecha, na metrópole, a Casa dos Estudantes do Império e a Associação dos escritores. Fecha toda a entidade cultural democrática, em Angola [...] Destrói as editoras e as gráficas. Proíbe a circulação da literatura angolana e leva para lá apenas os textos de qualidade inferior, comerciais, que não interessam à Europa. Enchem-se as prisões e o Tribunal Militar de Angola passa a um desempenho intenso. Renova-se a mentalidade de que a história angolana é a portuguesa [...] Entretanto, o tempo, a consciência e, sobretudo, o sentimento já não são os mesmos e a guerrilha pela libertação ganha a colônia (TUTIKIAN, 2006, p. 95).

Os angolanos, prejudicados politica, social e culturalmente durante o período colonial, assim como outros países africanos, entendiam ser necessário buscar a independência do país e, com a resistência de Portugal, a guerra tornou-se inevitável:

Por paradoxal que possa parecer, somos forçados a conceber que a guerra pode bem não ser mais do que um meio inoportuno para a instalação da paz 'perene', pois ela mostra-se capaz de construir as vastas unidades no seio das quais um poder central torna impossíveis novas guerras. Todavia, ela não alcança este resultado, pois o êxito da conquista é, regra geral, de curta duração, e as unidades recentemente criadas desagregam-se por sua vez, quase sempre por falta de coesão entre as partes reunidas pela força (FREUD, 2007, p. 46-47).

A Guerra Colonial era um meio necessário para alcançarem a independência e a paz em Angola após anos de subjugação de seu povo. Entretanto, quando o processo de descolonização começou em 1974, outra guerra assolou o país, a Guerra Civil Angolana, para decidir qual partido ficaria no poder. O partido vencedor, que governa o país até hoje, é o MPLA, movimento do qual o autor Pepetela era integrante.

O escritor Artur Carlos Maurício Pestana dos Santos, conhecido por Pepetela - uma palavra de origem umbundo que traduz o sobrenome Pestana -, nasceu em Benguela em 29 de outubro de 1941. Foi Secretário Permanente de Educação na Frente de Cabinda de Guerrilha no final dos anos 1960. Passou para a Frente Leste em 1972 e, em 1973, tornouse Secretário Permanente do Departamento de Educação e Cultura. Desempenhou a função de vice-ministro da Educação entre 1975 e 1982. Depois, deixou os cargos políticos e, formado em Sociologia, foi docente da Universidade de Angola. Fez parte, também, da Comissão Diretiva dos Escritores Angolanos (UEA).

O autor publicou muitos romances, destacando-se: As Aventuras de Ngunga (1973); Mayombe (1980); Lueji (1989); Geração da Utopia (1992); O Desejo de Kianda (1995); A Gloriosa Família (1997); Jaime Bunda, Agente Secreto (2001); Predadores (2005); O Planalto e a Estepe (2009); A Sul. O Sombreiro (2011); e duas peças, A Corda (1978) e A Revolta da Casa dos Ídolos (1980).

A obra de Pepetela, assim como a de outros escritores africanos, mostra a história de Angola desde a época anterior ao colonialismo, como em A Gloriosa Família, durante a luta pela independência, no Mayombe, até a contemporaneidade, em Predadores, denunciando os problemas do país e criticando as classes dominantes. 


\section{Mayombe foi escrito}

nos fins de noite, mais precisamente das 22 às 24 horas, durante um ano, em plena floresta de Cabinda, onde o autor lutava, Mayombe gira, na sua essência, em torno da problemática dos valores e das contradições da guerrilha (PEPETELA, 1982, p. 1).

Assim, desde a apresentação do livro, o leitor fica ciente da situação em que a obra foi criada, quando o autor guerreava contra os portugueses. E não foi algo planejado, segundo o autor, a escrita iniciou a partir de um comunicado de guerra:

Mayombe é um livro que foi feito sem projeto. Esse livro apareceu dum comunicado de guerra. Nós fizemos uma operação militar e eu era o responsável por mandar informações, redigir o comunicado, como tinha passado a operação e enviar depois para o nosso departamento de informação, que veiculava no rádio, no jornal. Eu escrevi aquela operação com que o livro começa e que é real. Acabei de escrever o comunicado, uma coisa objetiva, assim fria. E não foi nada disso que se passou. E continuei o comunicado, tirei a primeira parte e mandei pra eles, no departamento de informações e continuei (PEPETELA apud FORNOS, 2006, p. 48).

Vale ressaltar o fato de que, embora tenha sido escrita em 1971, a obra foi publicada somente em 1980, cinco anos após a independência, quando já não apresentava riscos de ser utilizada de alguma maneira pelos inimigos contra o MPLA, visto que mostrava o funcionamento interno do movimento.

Livro redigido concomitantemente à Guerra Colonial, Mayombe traz as experiências de Pepetela como guerrilheiro e os vários tipos de combatentes com os quais ele convivia, podendo ser vista como uma obra de testemunho, até porque o escritor afirma, em uma entrevista, dois motivos para a escrita da obra que vão ao encontro dessa teoria. sidade:

Primeiro, ele assegura que não tinha intenção de publicar e que escreveu por neces-

Eu escrevi não para publicar. Escrevi porque tinha necessidade de escrever. Estava em cima de uma realidade que quase exigia que eu escrevesse. Escrevendo eu compreendia melhor essa realidade; escrevendo eu atuaria também melhor sobre a própria realidade. Não quanto à obra escrita, mas pela minha atuação militante para melhor compreensão dos fenômenos que se passaram. Mas escrevia também para compreender melhor esses fenômenos. Claro que podia fazê-lo com um ensaio acadêmico, não era essa a minha intenção. Eu vejo a coisa como ficcionista (PEPETELA, 1999, p. 136).

Como forma de entender o que acontecia à sua volta, o autor percebeu que era preciso escrever, narrar, para aguentar as experiências traumáticas da guerra. O papel tornavase, assim, um mecanismo de fuga, auxiliando o autor que se via na tensão entre vida e morte que toda guerra propicia.

Margarida C. Ribeiro aponta para os estudos de W. H. R. Rivers, o qual acreditava que repreender memórias de guerra, tratamento utilizado com os soldados, não ajudava os pacientes a superar os traumas. O psiquiatra acreditava que "a melhor forma de abordar o problema e seguir uma terapia eficiente era precisamente dar oportunidade ao paciente de falar das suas experiências, seguindo o princípio da catarse, por oposição ao princípio da repressão" (RIBEIRO, 2011, p. 2). 
Nesse sentido, ao invés de repreender essas lembranças, fazia-se necessário para os soldados contar suas vivências a alguém para superar as perturbações. Porém, na falta de um conselheiro, Pepetela viu, na escrita, uma forma de amenizar as angústias que a situação de guerra impusera a ele.

Margarida C. Ribeiro ainda afirma que a escrita de livros sobre a guerra é feita não só por uma questão pessoal de pesquisa das palavras justas para exorcizar essa experiência autobiográfica traumática para sempre inacabada, mas também por uma questão social, política e literária de afirmação contra o silêncio coletivo inerente à funcionalidade pública do testemunho (2011, p. 7).

Dessa forma, além de nascerem a partir da necessidade interior de contar que movia - e que ainda move - os escritores combatentes, as narrativas de guerra tornam-se um modo de evitar o silêncio coletivo, que resulta no esquecimento daqueles que viveram durante esse período e no desconhecimento das próximas gerações sobre o que efetivamente aconteceu. Como afirmou Pepetela sobre sua obra:

Outro objetivo é que daqui a uns tempos não haverá pessoas que tenham vivido a situação colonial por "dentro". E toda a nova geração deverá ouvir falar, apenas. Há de haver textos de história sobre o que era o colonialismo, o que era a mentalidade do colono, etc., mas forçosamente texto de história, é uma coisa fria... e as pessoas acabam por imaginar o que seria, mas não compreender profundamente, e aí é o papel do romance, fundamental, para a nova geração conseguir "viver" um pouco o que era a vida antes. Aí há também uma preocupação de registrar para a história. E há pouca gente que escreve, que tenha tido essa vivência. E aí eu pensei, eu tenho essa vivência da sociedade colonial, eu tenho a vivência dos que se opuseram à sociedade colonial [...] Enfim, é um voltar atrás mas com os olhos pelo menos no presente (1999, p. 138-139).

Esse "voltar atrás" mas olhando para o presente é fundamental para estudar a memória, já que, segundo Benjamin, além de ser preciso estar ciente do confronto entre lembrança e esquecimento que ela abrange, é necessário considerar a conexão entre passado e presente. Nesse sentido, a escrita torna-se

um trabalho de elaboração e de luto em relação ao passado, realizado por meio de um esforço de compreensão e de esclarecimento - do passado e, também, do presente. Um trabalho que, certamente, lembra dos mortos, por piedade e fidelidade, mas também por amor e atenção aos vivos (GAGNEBIN, 2006, p. 105).

Essa elaboração do passado colabora para a compreensão do presente e a reflexão sobre o futuro. De acordo com Gagnebin,

a lembrança do passado desperta no presente o eco de um futuro perdido do qual a ação política deve, hoje, dar conta. Certamente, o passado já se foi e, por isso, não pode ser reencontrado 'fora do tempo', numa beleza ideal que a arte teria por tarefa traduzir; mas ele não permanece definitivamente estanque, irremediavelmente dobrado sobre si mesmo; depende da ação presente penetrar sua opacidade e retomar o fio de uma história que havia se exaurido $(2009$, p. 89).

E é a literatura que permite essa tarefa de retomada, pois, assim como Pepetela, outros escritores também deixaram relegada, ao narrador, a função de 
transmitir o que a tradição, oficial ou dominante, justamente não recorda. Essa tarefa paradoxal consiste, então, na transmissão do inenarrável, numa fidelidade ao passado e aos mortos, mesmo - principalmente - quando não conhecemos nem seu nome nem seu sentido (GAGNEBIN, 2006, p. 54).

Nesse conflito entre a tradição oficial, isto é, legitimada, e a memória de testemunhas, "Ricoeur defende a tese de uma justa memória, que leve em conta a ideia de um dever de memória, bem como a de uma dívida junto às vítimas da história" (UMBACH, 2010, p. 177). Assim, tanto a história escrita pelos historiadores quanto a literatura tem o dever de fazer justiça, ou seja, devem uma fidelidade ao passado e, principalmente, a aqueles que lutaram nesse passado.

Nesse sentido, a abertura de Mayombe é exemplar, pois Pepetela dedica a obra "aos guerrilheiros do Mayombe, que ousaram desafiar os deuses abrindo um caminho na floresta obscura" (1982, p. 3). Ao oferecer o livro aos seus companheiros, o autor mostra-se preocupado com o dever de memória, colaborando para o não esquecimento daqueles que lutaram na Guerra Colonial, numa forma de homenageá-los.

Se a história, muitas vezes, opta pela omissão de certos acontecimentos e pessoas, a literatura traz à tona outras versões do mesmo evento, principalmente, aquilo ou aqueles que foram esquecidos. A dedicatória é feita, então, a

aqueles que não têm nome, o anônimo [...] que foi tão bem apagado que mesmo a memória de sua existência não subsiste — aqueles que desapareceram tão por completo que ninguém lembra de seus nomes (GAGNEBIN, 2006, p. 54).

Da mesma maneira que Pepetela dedica a obra "aos guerrilheiros do Mayombe", de forma abrangente, a fim de que todos os combatentes possam sentir-se homenageados, o escritor, ao trazer personagens sem nomes próprios - apenas com nomes de guerra ${ }^{1}$ que condizem com as características físicas e/ou psicológicas delas, ou com a função que elas exercem dentro do grupo - , proporciona aos ex-guerrilheiros a identificação com qualquer uma das personagens.

Em Marxismo e crítica literária, Eagleton assinala que, para Plekhanov, Belinski e Lukács, "o escritor reflete a realidade de forma mais significativa ao criar 'tipos'; ele expressa uma 'individualidade histórica' em seus personagens, em vez de retratar apenas a psicologia individual" (2011, p. 83). Isso pode ser percebido na obra de Pepetela, pois o escritor não se refere a nenhum real companheiro seu de luta em especial, e, sim, a todos eles, já que apresenta diferentes tipos de combatentes que integravam o MPLA, colaborando para deixar marcada, na memória de todos, a contribuição desses homens na história de Angola.

Já que o testemunho tem "por certo o poder de fazer não esquecer" (RIBEIRO, 2011, p. 4), é por meio da literatura que vozes antes silenciadas poderão escrever sua própria história, o que, durante muito tempo, não lhes era permitido. Dessa forma, diferentes

\footnotetext{
${ }^{1}$ Exceto as personagens André e Ondina, os quais não participam da frente de batalha, nem entram no Mayombe, visto que o primeiro exerce o cargo de "responsável", e a segunda é professora em Dolisie. E, também, o Comissário que é chamado de João pela Ondina, quando não está na guerrilha.
} 
vozes permeiam a narrativa, discutindo questões essenciais do MPLA, inclusive fazendo denúncias contra ele, isto é, não simplesmente glorificando, mas mostrando a sua realidade.

Embora a narração em Mayombe seja, predominantemente, realizada por um narrador heterodiegético, as personagens assumem a posição de narrador em determinados momentos do livro. Esses trechos são iniciados por uma identificação - por exemplo: "Eu, o narrador, sou Teoria" (PEPETELA, 1982, p. 6); "Eu, o narrador, sou Milagre" (PEPETELA, 1982, p. 67) - e aparecem separados do resto do texto por um espaço antes e outro depois, além de se apresentarem grifados em itálico, o que os diferencia do narrador heterodiegético.

Nesse movimento de ganhar voz dentro da narrativa, além do habitual meio caracterizado pelo uso do diálogo, as personagens adquirem o direito de expor suas diversas opiniões sobre o MPLA, a guerra, seus efeitos e os motivos pessoais que os levaram até ela.

Cabe lembrar, aqui, uma das categorias que Fredric Jameson pontua, em War and Representation (2009), referentes às representações literárias sobre o tema guerra: a experiência existencial da guerra - que abrange uma experiência individual desta, podendo resultar num aprendizado ou trauma -, pois, mesmo que todas as personagens lutem pelo mesmo objetivo, a descolonização, os motivos individuais que as movem para a guerrilha são distintos, e cada uma vai vivenciar a guerra de um modo diferente.

Algumas das personagens terão maior destaque dentro da obra, figurando como principais, como Sem Medo, o Comissário Político, o Chefe de Operações, a Ondina, o André, o Teoria, mesmo que nem todas assumam o papel de narrador.

É o caso da personagem Sem Medo que, em nenhum momento, se posiciona como narrador, entretanto, é o que possui maior protagonismo nos diálogos e nos pensamentos relatados, sendo caracterizado de uma forma mais completa. Seu nome de guerra é explicado num momento da narrativa:

Quando foi promovido a Chefe de Secção, os guerrilheiros deram-lhe o nome de Sem Medo, por ter resistido sozinho a um grupo inimigo que atacara um posto avançado, o que deu tempo a que a Base fosse evacuada sem perdas. Uma das muitas operações em que rira do inimigo, sobre ele lançando balas, gracejos e insultos (PEPETELA, 1982, p. 10-11).

Sem Medo é chamado também de Comandante, já que chefia a tropa no interior do Mayombe junto com o Comissário e o Chefe de Operações, sendo respeitado por todos. Embora passe a imagem de herói corajoso aos outros combatentes, ele confessa ao Teoria qual é o seu medo:

Não tenho propriamente medo da morte, assim, a frio. Tenho medo é de me amedrontar quando vir que vou morrer, e perder o respeito por mim próprio. Deve ser horrível morrer com a sensação que os últimos instantes de vida destruíram toda a ideia que se tem de si próprio (PEPETELA, 1982, p. 45).

A concepção de herói bravo e justo que ele tem de si mesmo é vista também pelos seus companheiros, principalmente pelo Comissário, o qual enxergava em Sem Medo um modelo a ser seguido, ao mesmo tempo em que esse último o tratava como um filho: "Sem Medo viu os olhos luminosos do Comissário, procurando nos seus a aprovação" (PEPETELA, 1982, p. 183). 
No entanto, essa relação fraternal acaba se rompendo, temporariamente, quando o Comissário descobre que, em vez de convencer Ondina a continuar com ele, Sem Medo entende as razões da moça e a apoia. No primeiro momento, quando o Comissário sente-se traído e tem atitudes extremadas, o Comandante entra em conflito com o outro, mas compreende, logo depois, as atitudes dele, entendendo isso como um amadurecimento necessário: "O primeiro impulso de Sem Medo foi pegar no jipe para o impedir [...] Mas depois deixou-se cair na cadeira. Continuo a reagir como pai! Ele desembrulha-se" (PEPETELA, 1982, pág. 198).

O motivo individual que guiou Sem Medo para a guerrilha era a culpa. Sentia-se culpado pela morte da sua amada, Leli, por ela ter sido assassinada pela UPA, tentando chegar ao Congo, onde ele se encontrava. Sem Medo enfatiza, ainda, o fato de que ela era mestiça, sugerindo ter sido esta a razão da sua morte.

Ele entendia a guerrilha como um meio de fugir dessa culpa, de esquecer seu passado, entretanto, a figura de Leli o acompanhava através de visões e sonhos, atordoando-o, principalmente, nos instantes de maior perigo:

na espera, as recordações tristes da meninice misturavam-se à saudade dos amigos mortos em combate e mesmo (ou sobretudo) ao rosto de Leli. [...] Ao irem atacar o Posto de Miconje, a imagem de Leli viera confundir-se com a chuva [...] Fora aí, na cegueira da floresta e da chuva, que Leli viera, se impusera de novo. A angústia perseguiu-o até dar a ordem de fogo. O grito de fogo saíra-lhe como uma libertação, um urro de animal fugindo da armadilha. O grito ferido de Sem Medo afugentara a imagem de Leli (PEPETELA, 1982, p. 51).

A imagem de Leli se junta à tensão da espera do ataque, não de modo reconfortante ao combatente, mas, pelo contrário, impondo-se a ele de forma que o angustiava, porque Sem Medo via em seus olhos, "vingativos e meigos", a acusação "de mil crimes" (PEPETELA, 1982, p. 51).

Sem Medo era um bom conselheiro, pois ouvia os guerrilheiros e ajudava-os a superar seus temores, incentivando-os à reflexão. Possuía, também, a capacidade de distanciarse da situação e de olhá-la criticamente, como nos conflitos tribalistas nos quais, mesmo ele sendo kikongo, procurava ser imparcial e agir como conciliador do grupo, buscando sua unidade. Ou, ainda, quando analisava seus companheiros:

Lutamos está nervoso, inquieto, notou Sem Medo. O Teoria está a sofrer, mas finge que não. O Ekuikui... esse é sempre o mesmo. Ingratidão está desconfiado do Lutamos. Mundo Novo deve estar a pensar na Europa e nos seus marxistas-leninistas. Os pensamentos do Comandante não iam mais longe. Eram fotografias que tirava aos elementos do grupo e que classificava num ficheiro mental, sem mais se preocupar. Quando necessário, servia-se dessas informações para ter uma imagem fiel de cada guerrilheiro e saber que tarefa dar a cada um (PEPETELA, 1982, p. 21).

O Comandante mantém, de maneira enérgica, durante toda a obra, sua posição ideológica. Ele queria a revolução, sabia que a independência era necessária, mas não acreditava que o marxismo - ideologia do MPLA - funcionava na prática: "- A receita prática? Não ta posso dar. É como o marxismo. Serve de guia, de inspirador para a ação, mas não te resolve os problemas práticos..." (PEPETELA, 1982, p. 99). 
Assim, ao mesmo tempo que não conseguia imaginar-se na Angola liberta, ele questionava o futuro da nação.

- Eu? Não me vejo. Simplesmente, e em toda a sinceridade, não me vejo. Isso é que vos choca? [...] - A ti vejo-te claramente, como um quadro político. A mim, não me vejo. Talvez noutro país em luta... Quem sabe se na cadeia? Não me vejo em Angola independente. $\mathrm{O}$ que me não impede de lutar por essa independência (PEPETELA, 1982, p. 125-126).

Sem Medo morre, no final da narrativa, para salvar o Comissário, demonstrando sua valentia no combate e sua extrema dedicação ao movimento de libertação.

Outra personagem a ser destacada é o Comissário Político, descrito como um jovem alto e magro, idealista e inexperiente. Ele tem 25 anos, dez a menos que o Comandante, e, ao contrário deste, configura-se como um herói em formação.

O motivo pessoal que o levou à guerrilha é vingar seu pai, sua família, sendo citado logo no começo do texto: "Porquê o Comissário abandonara Caxito, o pai velho e pobre camponês arruinado pelo roubo das terras de café, e viera? Talvez o Comissário tivesse uma razão mais evidente que os outros, sim" (PEPETELA, 1982, p. 11).

Ao contrário de Sem Medo, acreditava cegamente no movimento, não percebendo a impossibilidade de aplicar a ideologia marxista na prática, e via o futuro de Angola de forma utópica. Por isso, e por ser sua função como comissário político, tenta conscientizar a população da região em que eles se encontravam.

Opondo-se aos pensamentos do Chefe de Operações, o Comissário defendia que a

guerra popular não se mede em número de inimigos mortos. Ela mede-se pelo apoio popular que se tem. [...] Com as armas e com a politização. Temos de mostrar primeiro que não somos bandidos, que não matamos o povo. $\mathrm{O}$ povo daqui não nos conhece, só ouve a propaganda inimiga, tem medo de nós. Se apanharmos os trabalhadores, os tratarmos bem, discutirmos com eles e, mais tarde, dermos uma boa porrada no tuga, então sim, o povo começa a acreditar e a aceitar (PEPETELA, 1982, p. 23-24).

Assim, o conflito de ideias dos dois guerrilheiros atravessa a obra, já que um sempre adota uma posição contrária ao outro e disputa a aprovação do Comandante. Num momento da narrativa, o Comissário reclama das atitudes do Chefe de Operações para o Sem Medo:

- Simplesmente que, desde que tu e eu não estejamos de acordo, vocês são dois e eu um: O Das Operações vai sempre pelo teu lado [...] - Ou porque sou o Comandante e deve apoiar-se para estar bem comigo e poder subir... ou porque tu és o Comissário, cargo logo a seguir ao dele, e deve estar contra ti, destruir-te, mostrar os teus erros, para apanhar o teu lugar [...] -Também me parece que sim - disse o Comissário [...] Quando eu estou, ele comete erros só para me contradizer. Não porque eu tenha sempre razão, mas às vezes também tenho... (PEPETELA, 1982, p. 15-16).

E o Comissário demonstra ter razão, principalmente, porque alcança o apoio do povo no final do livro. Quando os guerrilheiros, ao fazer um assalto, apreendem um grupo de trabalhadores angolanos e levam-nos para conversar sobre as intenções do movimento e conscientizá-los da necessidade da revolução, um do grupo, o mecânico, é roubado. Depois 
de os trabalhadores irem embora para suas casas, uma investigação é feita pelos comandantes, e o responsável pela ação é descoberto e preso.

O Comissário torna-se o único que insiste em ir até a aldeia e devolver o dinheiro, pois todos os outros acreditam ser desnecessário e perigoso. Entretanto, quando ele consegue falar com o mecânico, este doa o dinheiro ao movimento.

No final, o mecânico aparece em Dolisie e conversa com Sem Medo, disponibilizando-se a entrar para a luta, além de afirmar que outros da sua aldeia também desejam participar:

- Quero trabalhar no Movimento. Saí do kimbo ontem de manhã, cheguei ao Congo sem problemas. Venho apresentar-me [...] aquela conversa que os camaradas tiveram conosco começou a convencer-me. Realmente nós somos explorados e devemos lutar. Mas o que me convenceu mesmo foi quando os camaradas se arriscaram tanto para me devolver o dinheiro. Aí, sim, eu compreendi tudo. Os camaradas eram mesmo para defender o povo. [...] O povo está a compreender quem é afinal bandido! (PEPETELA, 1982, p. 250-251).

Dessa forma, graças à ação do Comissário, o MPLA ganha força com o apoio dos trabalhadores, como bem expressou Sem Medo nos últimos instantes de vida: "Olha! A classe operária adere à luta... Já vencemos..." (PEPETELA, 1982, p. 265).

O Comissário se modifica ao longo do texto, no entanto, o momento em que ocorre uma transformação mais significativa é quando descobre a traição de Ondina com André e a falta de apoio de Sem Medo para resolver isso. Primeiro, o relacionamento morno, que o Comissário mantinha com ela, muda, e ele aprende a superar a traição. Segundo, ao sentirse traído por Sem Medo, ele o enfrenta, ofendendo-o, e volta para o interior do Mayombe para comandar a Base no lugar do outro.

No final, devido à morte de Sem Medo, o Comissário parece compreender a mudança pela qual passava. Como último narrador da obra, afirma:

A morte de Sem Medo constituiu para mim a mudança de pele dos vinte e cinco anos, a metamorfose. Dolorosa, como toda metamorfose. Só me apercebi do que perdera [...] quando o inevitável se deu. [...] Eu evoluo e construo uma nova pele. Há os que precisam de escrever para despir a pele que lhes não cabe já. Outros mudam de país. Outros de amante. Outros de nome ou de penteado. Eu perdi o amigo (PEPETELA, 1982, p. 268).

Enquanto o Comissário passa por essa transformação na narrativa, outras personagens permanecem estáveis, e seus ideais não sofrem mudanças do início ao fim do enredo. Entretanto, isso não significa que elas não tenham importância dentro da obra, pois seus motivos individuais para estarem naquela guerra são, igualmente, enfatizados durante o transcorrer da ação.

Como ocorre à personagem Teoria que, ao assumir a posição de narrador, explica as dificuldades decorrentes da circunstância de ser mestiço numa luta entre brancos e negros:

Nasci na Gabela, na terra do café. Da terra recebi a cor escura de café, vinda da mãe, misturada ao branco defunto do meu pai, comerciante português. Trago em mim o inconciliável e é este o meu motor. Num Universo de sim ou não, branco ou negro, eu represento o talvez. [...] Face a este problema capital, as pessoas dividem-se aos meus 
olhos em dois grupos: os maniqueístas e os outros. É bom esclarecer que raros são os outros, o Mundo é geralmente maniqueísta (PEPETELA, 1982, p. 6-7).

Teoria lamenta o racismo e vê, na guerra, uma chance para mostrar o seu valor, afirmar-se, mas teve que abrir mão da sua amada e da situação privilegiada que tinha:

Perdi Manuela para ganhar o direito de ser "talvez", café-com-leite, combinação, híbrido, o que quiserem. [...] Estou no Mayombe, renunciando a Manuela, com o fim de arranjar no Universo maniqueísta o lugar para o talvez. [...] E Manuela, como poderia ela situar-se na vida de alguém perseguido pelo problema da escolha, do sim ou do não? [...] a minha vida é o esforço de mostrar a uns e a outros que há sempre lugar para o talvez (PEPETELA, 1982, p. 12).

Assim, sofre com sua condição existencial e participa da guerrilha para buscar seu lugar na sociedade, assemelhando-se à situação do Lutamos que, embora não seja mestiço, é o único da tribo dele naquele grupo, o que também o faz sentir-se isolado.

Vamos amanhã avançar para o Pau Caído [...] O Pau Caído ocupado pelo inimigo representa mais um punhal no povo de Cabinda. E onde está esse povo? Deixa-se dominar, não nos apoia [...] Amanhã, no ataque, quantos naturais de Cabinda haverá? Um, eu mesmo. Um, no meio de cinquenta. Como convencer os guerrilheiros de outras regiões que o meu povo não é só feito de traidores? Como os convencer que eu próprio não sou traidor? [...] Terei de ser eu a impor-me, sendo mais corajoso que ninguém. $\mathrm{E}$ Nzambi sabe como tenho medo! Mas que será feito do meu povo se o único cabinda se portar mal? (PEPETELA, 1982, p. 257-258).

A preocupação a guiar Lutamos na guerra é mostrar que seu povo não é traidor, que não está do lado dos portugueses, e demonstra isso quando se arrisca e morre para salvar outro combatente.

Ao mesmo tempo em que as situações de Lutamos e Teoria se assemelham, outras duas personagens têm motivos individuais para estar na guerrilha que também são similares entre si. O Milagre e o Muatiânvua, ambos órfãos, são dois combatentes que presenciaram a exploração e a crueldade provenientes do colonialismo.

Muatiânvua, ao colocar-se como narrador, conta:

O meu pai cavou com a picareta a terra virgem, carregou vagões de terra, que ia ser separada para dela se libertarem os diamantes. Morreu num hospital da Companhia, tuberculoso. O meu pai pegou com as mãos rudes milhares de escudos de diamantes. A nós não deixou um só, nem sequer o salário de um mês. O diamante entrou-lhe no peito, chupou-lhe a força, chupou, até que ele morreu. O brilho do diamante são as lágrimas dos trabalhadores da Companhia. A dureza do diamante é ilusão: não é mais que gotas de suor esmagadas pelas toneladas de terra que o cobrem. Nasci no meio de diamantes, sem os ver (PEPETELA, 1982, p. 131-132).

E Milagre, também através da voz do narrador, relata as atrocidades que viu quando ainda criança:

A minha terra é rica em café, mas o meu pai sempre foi um pobre camponês [...] Era miúdo na altura de 1961. Mas lembro-me ainda das cenas de crianças atiradas contra as árvores, de homens enterrados até ao pescoço, cabeça de fora, e o trator passando, cortando as cabeças com a lâmina feita para abrir terra, para dar riqueza aos homens. Com 
que prazer destruí há bocado o buldôzer! Era parecido com aquele que arrancou a cabeça do meu pai. O buldôzer não tem culpa, depende de quem o guia, é como a arma que se empunha (PEPETELA, 1982, p. 32).

Nos dois casos, seus pais eram trabalhadores de terras ricas - uma com diamantes, outra com café -, entretanto, devido à exploração dos tempos coloniais, morreram pobres e deixaram as famílias em semelhante situação de miséria. Nesse sentido, são as condições de vida e morte dos pais de Milagre e Muatiânvua que alimentam a vontade de vingança e a luta contra o colonialismo.

Assim, cada combatente tem motivos pessoais para estar na guerra, mas todos buscam o mesmo ideal, a descolonização. Acreditam que o movimento trará a independência para Angola, mesmo com suas dificuldades. Todas essas dificuldades configuram-se como experiências coletivas de guerra das personagens - outra variante proposta por Fredric Jameson -, pois afetam o grupo de combatentes e interferem, negativamente, na luta.

Pepetela critica o MPLA ao trazer questões que prejudicavam o movimento, como a falta de pessoas para compor o comando em Dolisie e os poucos guerrilheiros que haviam naquela região: "- Somos dezesseis. Ficaremos catorze. Matemática simples que resolvera a questão: era difícil conseguir-se um efetivo suficiente" (PEPETELA, 1982, p. 6).

Outra denúncia diz respeito ao mau uso dos recursos destinados à guerra, pois os militantes conviviam com a escassez de comida no interior do Mayombe. E, quando solicitam alimentos em Dolisie, André alega que falta dinheiro para comprar comida e enviar aos combatentes; no entanto, as refeições dele e de sua família são fartas.

$\mathrm{O}$ tribalismo ${ }^{2}$ constitui outra dificuldade experimentada pelo movimento de libertação, aparecendo de forma negativa em vários momentos da narrativa, como quando o Comandante pede voluntários para voltar e buscar um companheiro durante uma batalha, e todos hesitam:

- Ninguém se queria oferecer, porque Muatiânvua é um destribalizado. Fosse ele kikongo ou kimbundo e logo quatro ou cinco se ofereceriam... Quem foi? Lutamos, que é cabinda, e Ekuikui, que é umbundo. Uns destribalizados como ele, pois aqui não há outros cabindas ou umbundos... É assim que vamos ganhar a guerra? (PEPETELA, 1982, p. 55).

Os guerrilheiros que buscam Muatiânvua são aqueles que estão na mesma condição em que ele está, isto é, destribalizado, já que são os únicos de suas regiões no grupo. Nesse sentido, o tribalismo enfraquece o MPLA, impedindo sua unidade e fazendo com que a população não acredite na força do movimento.

Entretanto, essa situação é revertida em três momentos no final do livro. Uma delas ocorre quando o mecânico vai a Dolisie avisar que ele e sua aldeia querem, de alguma

\footnotetext{
${ }^{2} \mathrm{O}$ termo tribalismo refere-se, nesse caso, ao ato de priorizar interesses de determinada tribo em detrimento de outra. O MPLA era formado por guerrilheiros de diferentes tribos de Angola - Kimbundo, Kikongo, Umbundo, etc. - que nem sempre eram amigáveis entre si. Isso gerava rivalidades e desconfianças entre os combatentes, e "fazer tribalismo" era uma atitude condenável que ia de encontro à proposta de unificação do Movimento.
} 
forma, ajudar o movimento. Outra é a mobilização realizada por Sem Medo, em Dolisie, quando ele achava que a Base no interior do Mayombe tinha sido invadida pelos brancos:

Mobilizamos mais de trinta homens em menos de uma hora, com civis no meio. Sabem o que isso significa? Se não sabem, não percebo por que estão aqui a dizer que lutam. Foi o mais extraordinário sinal de solidariedade coletiva que vi. E de espírito combativo (PEPETELA, 1982, p. 240).

Assim, mesmo que tenha sido um engano - o "invasor" era apenas uma surucucu -, o Comandante fica feliz em constatar que todos os homens de Dolisie foram voluntários para a luta.

Por último, o episódio da morte de Lutamos e Sem Medo é um exemplo para os outros combatentes que deixavam se levar pelo tribalismo: "- Lutamos, que era cabinda, morreu para salvar um kimbundo. Sem Medo, que era kikongo, morreu para salvar um kimbundo. É uma grande lição para nós, camaradas" (PEPETELA, 1982, p. 267).

Dessa forma, através desses três eventos, verifica-se que o movimento consegue o apoio do povo, e o tribalismo parece ser superado, ou, no mínimo, atenuado ao final da narrativa.

Pepetela demonstra em Mayombe que, ao mesmo tempo que fazer a guerra "é um meio de se confrontarem com o outro eu" (PEPETELA, 1982, p. 233), a Guerra Colonial também foi um modo para os angolanos ultrapassarem suas diferenças e se unirem contra o colonialismo.

O autor também percebeu, quando militante, a importância de contar, conversando ou escrevendo, como uma forma de terapia, o que é enfatizado pela voz de Sem Medo:

Mas, quando se conta, pronto, tudo nos aparece mais claro e sentimo-nos livres. É bom conversar. Esse é dos tais problemas que pode destruir um indivíduo, se ele o guarda para si. [...] É bom falar, é bom conversar com um amigo, a quem se abre o coração. [...] Guardar para si não dá, só quando se é escritor. Aí um tipo põe tudo num papel, na boca dos outros. Mas, quando se não é escritor, é preciso desabafar, falando (PEPETELA, 1982, p. 43-44).

Além disso, a obra Mayombe torna-se constituinte de uma memória coletiva do povo de Angola, retratando a Guerra Colonial, já que, de acordo com Jacques Le Goff, “a memória, onde cresce a história, que por sua vez a alimenta, procura salvar o passado para servir o presente e o futuro. Devemos trabalhar de forma a que a memória coletiva sirva para a libertação e não para a servidão dos homens" (1990, p. 477).

Nesse sentido, a escrita foi entendida por Pepetela como um meio de suportar e compartilhar as angústias daquele tempo, como um registro para as próximas gerações que apenas ouvirão sobre a guerra, além de uma forma de honrar aqueles que participaram da luta pela independência de Angola.

\section{REFERÊNCIAS}

CORNELSEN, Elcio; BURNS, Tom (Org.). Literatura e guerra. Belo Horizonte: UFMG, 2010 .

EAGLETON, Terry. Marxismo e crítica literária. São Paulo: Editora UNESP, 2011. 
EINSTEIN, Albert; FREUD, Sigmund. Porquê a guerra? Mem Martins: Europa-América, 2007.

FORNOS, José Luís Giovanoni. Nacionalismo, revolução e pós-colonialismo: o caso Mayombe, de Pepetela. Letras de Hoje. Porto Alegre, v. 41, n. 3, p. 47-56, set. 2006.

GAGNEBIN, Jeanne Marie. Lembrar esquecer escrever. São Paulo: Ed. 34, 2006.

GAGNEBIN, Jeanne Marie. História e narração em Walter Benjamin. São Paulo: Perspectiva, 2009.

GOFF. Jacques Le. História e memória. São Paulo: Editora da UNICAMP, 1990.

JAMESON, Fredric. War and Representation. PMLA, Outubro 2009. V. 124, N. 5, p. 1532-1547.

OZ, Amós. Pantera no porão. São Paulo: Companhia das Letras, 1999.

PEPETELA. Mayombe. São Paulo: Ática, 1982.

PEPETELA. Entrevista com Pepetela. In: SERRANO, Carlos. O romance como documento social: o caso de Mayombe. Revista Via Atlântica. São Paulo, n. 3, p. 132-139, dez. 1999.

RIBEIRO, Margarida Calafate. Guerra, poesia e trauma: leituras da poesia da Guerra Colonial. Disponível em: <http://www.fchs.ualg.pt/xcail/comunicacoes/pdf/lc/Margarida_Ribeiro.pdf>. Acesso em: 10 de setembro de 2011.

TUTIKIAN, Jane. Velhas identidades novas: o pós-colonialismo e a emergência das nações de língua portuguesa. Porto Alegre: Sagra Luzzatto, 2006.

UMBACH, Rosani Ketzer. O dever de memória e a escrita autobiográfica. In: SCHMIDT, Rita Terezinha (Org.). Sob o signo do presente: intervenções comparatistas. Porto Alegre: Editora da UFRGS, 2010. p. 175-181.

Recebido em: 12/04/2015

Aceito em: 19/04/2015

\footnotetext{
${ }^{\text {i }}$ Mestre em Letras pela Universidade Federal do Rio Grande do Sul (2013). Professora das redes pública e privada de Canoas. Email: biancabratk@gmail.com.
} 